\title{
Meningkatkan Hasil Belajar melalui Model Pembelajaran Kooperatif Tipe Talking Stick
}

\author{
Lisnah, St. Marwiyah Fauziah Zainuddin \\ Prodi Pendidikan Agama Islam, IAIN Palopo \\ Email: lisnahpail@gmail.com
}

\begin{abstract}
This study discusses the application of the Talking Stick type Cooperative model in the Islamic Education Class IX3 class at SMP Negeri 8 Palopo with the subject of AI-Qur'an Hadith in the odd semester of the academic year 20172018. This research is Classroom Action Research. Learning outcomes data collected were analyzed using quantitative analysis and observational results were analyzed qualitatively. The study was conducted in two cycles each cycle carried out in 2 meetings with a total of 28 students consisting of 14 male students and 14 female students. Data retrieval is done by using observation sheets and test results of learning. The results showed the average learning outcomes of students before applying the Talking Stick 68.46 With classical learning completeness 75 after applying the Talking Stick model the results of the study showed the average learning outcomes of students in the first cycle was 79.25 and the cycle II of 88.53. Based on the results of this study it can be concluded that by applying it the Talking Stick model can improve the learning outcomes of Religious Education for Class IX3 Students of SMP Negeri 8 Palopo
\end{abstract}

Keywords: Kooperatife Learning, Talking Stick, learning outcomes, Islamic Education

\begin{abstract}
Abstrak
Penelitian ini menyelidiki Penerapan model kooperatif tipe Talking Stick pada pelajaran Pendidikan Agama Islam kelas IX3 SMP Negeri 8 Palopo, dengan pokok pembahasan Al-Qur'an Hadist pada semester ganjil tahun ajaran 2017/2018. Peneilitian ini merupakan Penelitian Tindakan Kelas. Data hasil belajar yang terkumpul di analisis dengan menggunakan analisis kuantitatif dan hasil observasi di analisis secara kualitatif. Peneletian dilaksanakan sebanyak dua siklus, masing-masing siklus dilaksanakan sebanyak 2 kali pertemuan dengan jumlah 28 peserta didik terdiri dari 14 peserta didik laki-laki dan 14 peserta didik perempuan. Pengambilan data dilakukan dengan menggunakan lembar observasi dan tes hasil belajar. Hasil Penelitian menunjukkan bahwa rata-rata hasil belajar peserta didik sebelum diterapkan Talking Stick 68,46\% Dengan ketuntasan belajar secara klasikal 75\% setelah penerapan model Talking Stick hasil penelitian menunjukkan bahwa rata-rata hasil belajar peserta didik pada siklus I sebesar $79.25 \%$ dan siklus II sebesar $88.53 \%$. Berdasarkan hasil penelitian ini dapat disimpulkan bahwa dengan diterapkanya model Talking Stick dapat meningkatkan hasil belajar Pendidikan Agama Islam Peserta didik kelas IX3 SMP Negeri 8 palopo.
\end{abstract}

Kata Kunci: Talking stick, Hasil Belajar. 


\section{Pendahuluan}

Peranan model pengajaran merupakan hal yang sangat penting dalam proses belajar mengajar karena model dapat dijadikan sebagai faktor penentu dalam keberhasilan mencapai tujuan yang ingin dicapai dalam proses belajar mengajar di sekolah. Oleh karena itu, guru sebagai informan dalam proses belajar mengajar, hendaknya menguasai beberapa model mengajar yang sesuai dengan pokok pembahasan yang akan disajikan karena dengan mengguakan model yang sesuai akan menghasilkan lancarnya proses belajar mengajar dan secara otomatis prestasi belajar peserta didik akan meningkat.

Para pedagog dan psikolog berpendapat bahwa belajar adalah suatu proses perubahan prilaku. Perilaku mengandung arti yang sangat luas, meliputi pengetahuan kemampuan berpikir, skill keterampilan, penghargaan terhadap suatu sikap, minat, dan semacamnya. Tidak semua perilaku merupakan hasil belajar, karena sebagian diakibatkan oleh proses perkembangan dan pertumbuhan, seperti antara lain kematangan (maturation), tetapi hal tersebut merupakan salah satu proses, ia membutuhkan waktu serta usaha, dan usaha itu memerlukan waktu, cara, dan model. 1

Fungsi guru Pendidikan Agama Islam adalah untuk memilih, menetapkan, dan mengembangkan model-model pembelajaran yang memungkinkan dapat membantu kemudahan, kecepatan, kebiasaan, dan kesenangan peserta didik mempelajari Islam untuk dijadikan pedoman dan petunjuk hidup dan kehidupannya. ${ }^{2}$

Berhubungan dengan model pembelajaran, model dapat diartikan sebagai cara-cara atau langkah-langkah yang diguakan menyampaikan sesuatu gagasan, pemikiran atau wawasan yang disusun secara sistematis dan terencana didasarkan pada teori, konsep, dan prinsip-prinsip tertentu. ${ }^{3}$

Agar pembelajaran Pendidikan Agama Islam menjadi pembelajaran yang aktif dan menyenangkan, salah satunya dapat dilaksanakan dengan penerapan model pembelajaran Talking Stick. Talking Stick merupakan sebuah model pembelajaran yang berorientasi pada penciptaan kondisi dan suasana belajar aktif dari peserta didik karena adanya unsur permainan dalam proses pembelajaran.

${ }^{1}$ Prof. Drs. H. Burhanuddin Salam, M.M. Cara Belajar yang Sukses di Perguruan Tinggi, (Jakarta, PT Rineka Cipta, 2014), h. 3

2 Muhaimin, Paradikma Pendidikan Islam: Upaya Mengefektifkan Pendidikan Agama Islam di Sekolah, (Cet. III; Bandung: Remaja Rosdakarya, 2004), h, 184.

3 Syamsu s, Strategi Pembelajaran Meningkatkan Kompotensi Guru, (Aksara Timur: September 2015), h. 89 
Adapun model Talking Stik adalah model yang pada mulanya digunakan oleh penduduk Amerika untuk mengajak semua orang berbicara atau menyampaikan pendapat dalam suatu forum. ${ }^{4}$ Model pembelajaran Talking Stick termasuk salah satu model pembelajaran koomperatif. Strategi pembelajaran ini dilakukan dengan bantuan tongkat, siapa yang memegang tongkat wajib menjawab pertanyaan dari guru setelah mempelajari materi pokoknya. Selain untuk melatih berbicara, pembelajaran ini akan menciptakan dan membuat aktif.

Pembelajaran dengan strategi Talking Stick mendorong untuk berani mengemukakan pendapat. Strategi ini diawali dengan pendapat.startegi ini diawali dengan penjelasan guru mengenai materi pokok yang akan dipelajari. Kemudian dengan bantuan stick (tongkat) yang bergulir dituntun untuk merefleksikan atau mengulang kembali materi yang sudah dipelajari dengan cara menjawab pertanyaan dari guru. Siapa yang memegang tongkat, dialah yang menjawab pertanyaan (talking). ${ }^{5}$ Dari penjelasan di atas dapat disimpulkan bahwa Talking Stick dipakai sebagai tanda seseorang mempunyai hak suara (berbicara) yang diberikan secara bergiliran/bergantian.

SMP Negeri 8 Palopo sebagai salah satu lembaga pendidikan yang sangat menjunjung keberhasilan pembelajaran, sehingga yang dihasilkan mampu berperan dalam persaingan global. Usaha ke arah tersebut sudah banyak dilakukan oleh pihak sekolah terkait, seperti pemenuhan sarana prasarana, media pembelajaran, guru yang profesional serta komponen lain yang mampu meningkatkan kualitas pendidikan yang dijalankan, dengan harapan mampu menciptakan manajemen pembelajaran dengan baik, yang pada akhirnya menjadikan sekolah berkualitas. Namun ternyata saat ini masih banyak permasalahan yang muncul di sekolah ini, di antaranya model ceramah masih menjadi pilihan dalam penyampain materi sehingga cenderung bosan, dan kurang bersemagat untuk belajar. Hal ini membuat kualitas pembelajaran menjadi rendah dan memungkinkan hasil belajar akan menurun. Model tanya jawab kurag efektif karena hanya yang pintar dan aktif yang mau menjawab pertanyaan yang diberikan, sehingga menjadi kesenjangan antara yang pintar dan yang kurang pintar, sedangkan dalam model diskusi tidak semua topik dapat disajikan dengan model diskusi. Hanya hal-hal yang bersifat problematis saja yang dapat didiskusikan. Diskusi yang mendalam memerlukan banyak waktu, sulit untuk menentukan batas luas atau ke dalaman suatu urain diskusi. Biasanya tidak semua berani menyatakan pendapat. sehingga waktu akan terbuang karena menunggu berani menyatakan pendapat. Pembicaraan dalam

4 Aris shoimin, 68 Model Pembelajaran Inovatif dalam Kurikulum 2013, (Cet. II; Yogyakarta: Juni 2016), h, 197.

${ }^{5}$ Ibid. h. 198 
diskusi mungkin didominasi oleh yang berani dan telah terbiasa berbicara. pemula dan pendiam tidak akan menggunakan kesempatan untuk berbicara.

Penelitian ini bertujuan untuk menyelidiki apakah penerpan model pemebelajaran talking stick dapat meningkatkan hasil belajar pendidikan agama Islam khususnya di SMP Negeri 8.

\section{Metode Penelitian}

Penelitian ini merupakan Penelitian Tindakan Kelas (PTK). Istilah dalam bahaha Inggris adalah Classroom Action Reserch (CAR). Penelitian ini direncanakan terdiri atas 2 siklus, subjek penelitian adalah peserta didik kelas $\mathrm{IX}_{3}$ SMP Negeri 8 Palopo dengan jumlah siswa 28 terdiri atas 14 pesrta didik laki-laki dan 14 peserta didik perempuan.

Waktu pelaksanaan penelitian ini dilaksanakan pada semester ganjil ajaran 2017/2018 di SMP Negeri 8 Palopo Data dalam penelitian ini berupa tuturan guru mitra dan peserta didik baik lisan maupun tulisan, video, gambar atau foto-foto yang memperlihatkan tindakan guru dan peserta didik dalam interaksi pembelajaran dengan menerapkan pembelajaran koomperatif dengan model Talking Stick dengan alat bantu lember observasi dan tes . Data kuantitatif (nilai hasil belajar siswa) yang dapat dianalisis secara deskriftif. Dalam hal ini peneliti menggunakan analisis statistik deskriptif. Misalnya mencari rata-rata nilai, persentase, keberhasilan belajar, dan sebagainya nilai hasil belajar peserta didik dapat dinyatakan dalam skala yaitu sebagai berikut. 6

Tabel 1 Skala Nilai Hasil Belajar Peserta Didik

\begin{tabular}{|c|c|}
\hline Kategori Angka 100 & Keterangan \\
\hline $86-95$ & Baik Sekalai \\
$76-85$ & Baik \\
$66-75$ & Cukup \\
$61-65$ & Kurang \\
$60-0$ & Kurang sekali \\
\hline
\end{tabular}

Data yang diperoleh dari hasil belajar siswa dapat ditentukan menggunakan analisis deskriptif presentase, degan perhitungan:

Ketuntasan belajar $=\frac{\text { jumlah yang tuntas }}{\text { jumlah } \text { siswa }} \times 100 \%$

Berdasarkan teori belajar tuntas maka seorang peserta didik dipandang tuntas belajar jika ia mampu menyelesaikan, menguasai kompetensi atau mencapai tujuan pembelajaran minimal $75 \%$ dari seluruh

\footnotetext{
${ }^{6}$ Suharsimi Arikunto, Dasar-dasar Evaluasi Pendidikan, (Cet, X, Jakarta: Bumi Aksara,
} 2009), H. 245. 
tujuan pembelajaran. Sedangkan keberhasilan kelas dilihat dari jumlah peserta didik yang mampu menyelesaikan atau mencapai minimal 75\%, sekurang-kurangnya $85 \%$ dari jumlah peserta didik yang ada dikelas tersebut. ${ }^{7}$

\section{Hasil Penelitian}

\section{Deskripsi Data Siklus I}

\section{Perencanaan}

Perencanaan yang telah dibuat terlebih dahulu sudah dikonsultasikan dengan guru mata pelajaran Pendidikan Agama Islam. Berdasarkan hasil diskusi antara guru dan peneliti, disepakati bahwa untuk siklus I materi yang akan dipelajari mengenai arti dari Al-Qur'an Surah At-Tin dengan bantuan buku yang ada. Hal-hal yang dilakukan pada tahap perencanaan ini antara lain sebagai berikut:

a. Membuat RPP (Rencana Pelaksanaan Pembelajaran) tentang materi yang akan diajarkan sesuai dengan penerapan model kooperatif tipe Salking Stick.

b. Mempersiapkan buku Pendidikan Agama Islam berupa buku cetak yang berhubungan dengan materi.

c. Menyusun dan menyiapkan lembar observasi kegiatan belajar peserta didik dengan penerapan model kooperatif tipe Talking Stick.

d. Membuat tes evaluasi untuk mengetahui peningakatan penguasaan mengenai materi yang diajarkan.

2. Pelaksanaan

Pelaksanaan merupakan implementasi dari semua rencana tindakan yang telah dibuat. Kegiatan yang dilaksanakan oleh peneliti pada tahap ini yakni:

a. Guru memberikan apersepsi tentang materi pembelajaran yang akan dibahas.

b. Guru menyampaikan tujuan pembelajaran.

c. Guru menulis materi pokok/sub materi pokok yang akan dibahas.

d. Menjelaskan dan mendemonstrasikan sesuatu prosedur atau proses yang didukung dengan menggunakan buku Pendidikan Agama Islam yang berkaitan dengan materi.

e. Peserta didik mengamati penjelasan dan demonstrasi dari guru dengan baik.

f. Guru memberi kesempatan kepada peserta didik untuk mencoba membaca sendiri.

${ }^{7}$ E. Muliasa, Kurikulum Berbasis Kompetensi: Konsep, Karakteristik, Implementasi, Dan Inovasi, (Cet, XI, Bandung: Remaja Rosdakaria, 2008), H. 99. 
g. Guru menjelaskan materi yang di ajarkan kepada peserta didik sambil member kesempatan kepada peserta didik untuk bertanya jika masih ada yang belum dimengerti.

h. peserta didik dalam praktik adalah peserta didik yang belajar maka perlu diberi petunjuk yang jelas, sebab mereka di samping memperoleh pengetahuan juga pengalaman.

i. Terakhir memberikan tes kepada peserta didik.

3. Pengamatan

Pengamatan adalah kegiatan yang dilaksanakan bersamaan dengan pelaksanaaan tindakan dengan melihat langsung kegiatan proses pembelajaran. Berdasarkan lembar observasi aktivitas peserta didik dengan penerapan model kooperatif tipe Talking Stick diperoleh hasil sebagai berikut:

a. Datang tepat waktu.

b. Hormat kepada Guru.

c. Memperhatikan guru saat proses pembelajaran sedang berlangsung.

d. Tidak keluar kelas saat Guru sedang menjelaskan

e. Memawa buku Pendidikan Agama Islam sesuai yang di sarankan guru.

f. Berani jika disuruh menjawab pertanyaan dari guru.

g. Mampu kerjasama Jika diberikan tugas membaca perkelompok.

h. Pada siklus pertama berdasarkan lembar observasi aktivitas peserta didik mencapai presentase $79.25 \%$.

4. Refleksi

Berdasarkan pengamatan peneliti selama proses pembelajaran Pendidikan Agama Islam berlangsung pada siklus pertama, pembelajaran dengan penerapan model kooperatif tipe Talking Stick sudah berjalan sesuai dengan prosedur yang telah direncanakan. Namun, sebagian peserta didik masih kurang berpartisipasi dalam mengikuti pembelajaran dengan serius. Selain, itu peserta didik masih merasa enggan dan malu untuk mengajukan pertanyaan kepada guru sehubungan dengan materi yang diajarkan. Pertanyaan hanya diajukan oleh sebagian kecil peserta didik pada siklus pertama berlangsung.

Permasalahan lain yang dapat diamati peneliti adalah peserta didik masih malu untuk menjawab pertanyaan dari guru. Terlihat pada hasil observasi siklus pertama keaktifan belajar peserta didik hanya mencapai presentase $79.25 \%$.

Adapun hasil belajar yang diperoleh peserta didik setelah menerapkan model kooperatif tipe Talking Stick. 
Tabel 2. Distribusi Frekuensi dan Presentase Skor Nilai Peserta didik Siklus I

\begin{tabular}{|c|c|c|c|c|}
\hline No & Nilai Angka & Kategori & Frekuensi & Persentase (\%) \\
\hline 1 & $0-60$ & Kurang Sekali & - & - \\
\hline 2 & $61-65$ & Kurang & 2 & $6,79 \%$ \\
\hline 3 & $66-75$ & Cukup & 6 & $20,36 \%$ \\
\hline 4 & $76-85$ & Baik & 17 & $57,68 \%$ \\
\hline 5 & $86-95$ & Baik Sekali & 3 & $10,18 \%$ \\
\hline \multicolumn{2}{|c|}{ Jumlah } & 28 & $95 \%$ \\
\hline
\end{tabular}

Sumber Data : Peserta Didik IX 3 SMP Negeri 8 Palopo, tanggal 26 juli 2017.

Untuk lebih jelasnya gambaran tes hasil belajar peserta didik siklus I kelas VII 9 SMP Negeri 8 Palopo dapat dilihat pada diagram berikut :

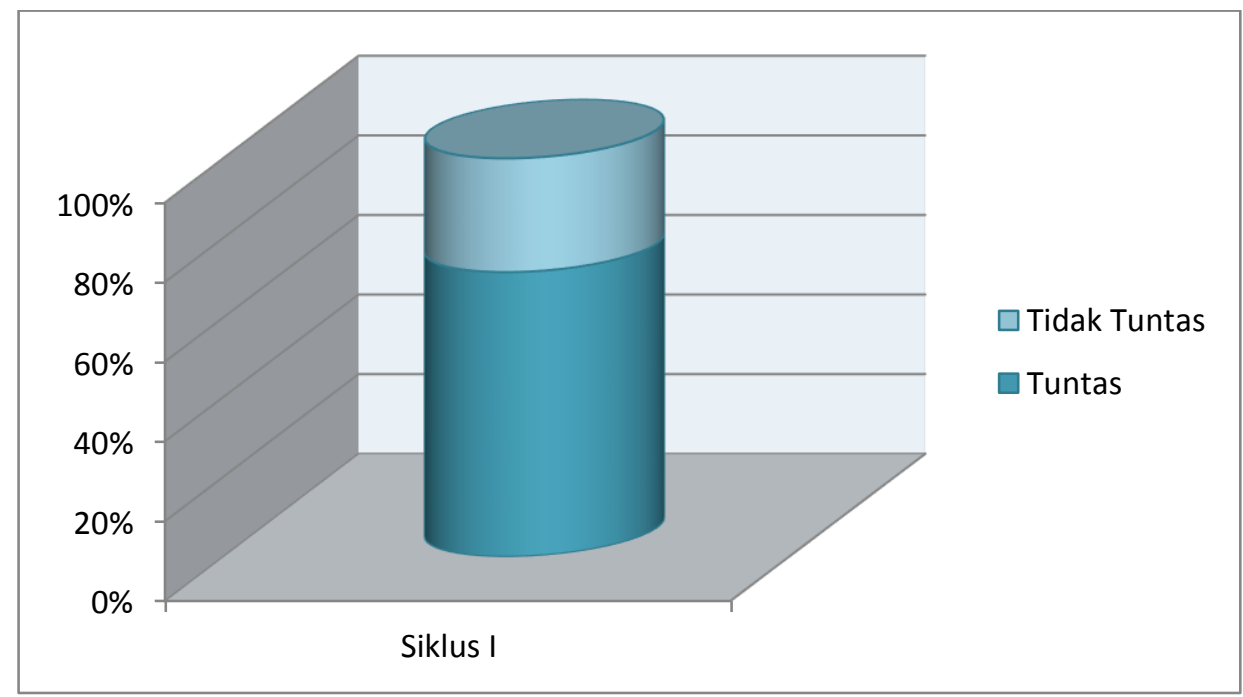

Gambar 1. Diagram ketuntasan Siklus I

Dengan demikian dapat disimpulkan bahwa hasil pembelajaran siklus I pada mata pelajaran Pendidikan Agama Islam kelas IX 3 SMP Negeri 8 palopo belum tuntas karena belum mencapai 80\%. Tingkat presentase hasil belajar peserta didik yang tuntas adalah $20 \%$ dan yang belum tuntas adalah $8 \%$. Dengan demikian untuk meningkatkan hasil belajar peserta didik diperlukan penelitian lanjutan ke siklus II dengan menggunakan model pembelajaran kooperatif tipe Salking Stick.

\section{Deskripsi Data Siklus II}

Dari permasalahan yang muncul pada siklus pertama, peneliti bersama guru merencanakan langkah-langkah perbaikan yang akan diterapkan pada siklus kedua. Untuk memperbaiki kelemahan dan mempertahankan keberhasilan yang telah dicapai pada siklus pertama maka pada siklus kedua dibuat perencanaan sebagai berikut: 
1. Memberikan motivasi kepada seluruh peserta didik khususnya untuk peserta didik yang masih kurang aktif dalam kegiatan pembelajaran tentang pentingnya mempelajari Al-Qur'an Hadist, khususnya Al-Qur'an Surah At-Tin.

2. Untuk mengatasi masalah peserta didik yang masih enggan atau malu menjawab pertanyaan di depan kelas, guru memberikan kesempatan pesera didik untuk menjawab pertanyaan yang di berikan dengan temannya secara kelompok atau 4-5 orang per kelompok selanjutnya guru memberikan kesempatan peserta didik untuk menjawab sendiri pertanyaan yang diberikan dengan menggunakan model Talking Stick secara individu.

3. Peneliti juga mengingatkan pada peserta didik untuk serius dalam mengerjakan evaluasi yang diberikan setelah pembelajaran untuk mengetahui peningkatan hasil belajar peserta didik dengan penerapan model pembelajaran dan tentunnya nilai yang mereka peroleh akan diberikan kepada guru mata pelajaran Pendidikan Agama Islam.

4. Peneliti juga memberikan motivasi kepada peserta didik pentingnya belajar Al-Qur'an Hadist dalam kehidupan sehari-hari, karena belajar merupakan kewajiban setiap muslim, karena dengan belajar kita mampu mengetahui apa yang tidak kita ketahui. Khususnya materi Al-Qur'an Surah AtTin.

a. Perencanaan

Pada tahap perencanaan peneliti menentukan fokus peristiwa yang perlu mendapatkan perhatian khusus untuk diamati, kemudian membuat sebuah instrumen pengamatan untuk merekam fakta yang terjadi selama tindakan berlangsung.

Berdasarkan hasil refleksi pada siklus pertama, perencanaan yang disusun untuk siklus kedua dilakukan dengan terlebih dahulu peneliti selalu memotivasi peserta didik agar aktif dalam proses pembelajaran dengan penerapan model kooperatif tipe Salking Stick.

Perencanaan siklus kedua juga disusun seperti pada siklus pertama, yaitu :

1. Membuat Rencana Pelaksanaan Pembelajaran (RPP) dengan Al-Qur'an Surah At-Tin dengan penerapan model kooperatif tipe Salking Stick.

2. Mempersiapkan buku pembelajaran pendidikan agama Islam sesuai materi yang diajarkan

3. Menyusun dan menyiapkan lembar observasi kegiatan belajar peserta didik dengan penerapan model kooperatif tipe Salking Stick.

4. Membuat tes evaluasi untuk mengetahui peningakatan penguasaan mengenai materi yang diajarkan.

b. Pelaksanaan 
Pelaksanaan merupakan implementasi dari semua rencana tindakan yang telah dibuat. Kegiatan yang dilaksanakan oleh peneliti pada tahap ini adalah sebagai berikut:

Guru memberikan apersepsi tentang materi pembelajaran yang akan dibahas.

1. Guru menyampaikan tujuan pembelajaran.

2. Guru menulis materi pokok/sub materi pokok yang akan dibahas di papan tulis.

3. Menjelaskan dan mendemonstrasikan sesuatu prosedur atau proses yang didukung dengan menggunakan bahan ajar tertentu, misalnya buku pendidikan agama Islam yang berkaitan dengan materi.

4. peserta didik mengamati penjelasan dan demonstrasi dari guru dengan baik.

5. Guru memberi kesempatan kepada peserta didik yang memegang tongkat untuk menjawab pertanyaan yang diberikan.

6. Selama praktik berlangsung, guru tetap mendampingi dan mengawasi peserta didik sehingga jika ada kesalahan dalam proses praktik guru dapat memberi arahan untuk menunjang kesempurnaan.

7. Peserta didik dalam praktik adalah peserta didik yang belajar maka perlu diberi petunjuk yang jelas, sebab mereka di samping memperoleh pengetahuan juga pengalaman.

8. Terakhir memberikan soal-soal latihan terhadap apa yang telah dipelajari.

c. Pengamatan

Pengamatan adalah kegiatan yang dilaksanakan bersamaan dengan pelaksanaaan tindakan dengan melihat langsung kegiatan proses pembelajaran. Pada tahap ini, peneliti melakukan pengamatan dan mencatat semua hal yang diperlukan dan terjadi selama pelaksanaan tindakan berlangsung. Berdasarkan lembar observasi aktivitas peserta didik dengan penerapan model kooperatif tipe Talking Stick diperoleh hasil sebagai berikut

1. Peserta didik sudah mulai terbiasa dengan model kooperatif tipe Salking Stick.

2. Peserta didik sudah berani untuk bertanya, menjawab pertanyaan serta mengemukakan pendapat,

3. Ketika dilakukan evaluasi peserta didik dapat menjawab dan menguasai mata pelajaran yang diberikan dengan penerapan model kooperatif tipe Salking Stick.

4. Pada siklus kedua berdasarkan lembar observasi aktivitas peserta didik mencapai presentase $88.53 \%$ 


\section{d. Refleksi}

Refleksi dilakukan untuk menentukan apakah siklus kedua harus diulangi atau sudah berhasil. Berdasarkan pengamatan peneliti selama pembelajaran berlangsung dalam siklus kedua, pembelajaran dengan penerapan model kooperatif tipe Talking Stick sudah berjalan sesuai dengan prosedur yang telah direncanakan dan selama pembelajaran berlangsung semua peserta didik sudah aktif dan berpartisipasi terlihat pada lembar observasi aktivitas peserta didik dengan penerapan model kooperatif tipe Talking Stic kdan hasil evaluasi tes belajar peserta didik pada siklus kedua mencapai rata-rata $88.53 \%$ lebih meningkat dibanding pada siklus pertama yang hanya mencapai rata-rata $79.25 \%$. Jadi, kriteria keberhasilan tindakan siklus ini sudah tercapai sehingga tidak perlu lagi diadakan tindakan atau dilanjutkan dengan siklus ketiga.

\section{Tabel 3. Distribusi Frekuensi dan Presentase Skor Nilai Peserta didik} Siklus II

\begin{tabular}{|c|c|c|c|c|}
\hline No & Nilai Angka & Kategori & Frekuensi & Persentase (\%) \\
\hline 1 & $0-60$ & Kurang Sekali & - & \\
\hline 2 & $61-65$ & Kurang & - & \\
\hline 3 & $66-75$ & Cukup & - & \\
\hline 4 & $76-85$ & Baik & 7 & $23,75 \%$ \\
\hline 5 & $86-95$ & Baik Sekali & 21 & $71,25 \%$ \\
\hline \multicolumn{3}{|c|}{ Jumlah } & 28 & $95 \%$ \\
\hline
\end{tabular}

Sumber Data : Peserta Didik IX 3 SMP Negeri 8 Palopo, tanggal 02 Agustus 2017.

Dengan demikian dapat disimpulkan bahwa hasil pembelajaran siklus II pada mata pelajaran Pendidikan Agama Islam kelas IX 3 SMP Negeri 8 palopo meningkat karena tingkat karena telah mencapai 80\%, presentase hasil belajar peserta didik yang tuntas adalah $28 \%$. Dengan demikian menggunakan model pembelajaran kooperatif tipe Talking Stick dapat meningkatkan hasil belajar peserta didik.

Berdasarkan tabel 4.9 di atas menunjukan skor hasil tes belajar peserta didik siklus kedua rata-rata 88.53 dan selanjutnya peneliti mengklasifikasi nilai-nilai tersebut berdasarkan tingkat keberhasilan sebagaimana tabel sebagai berikut : 
Tabel 4.10

Distribusi Frekuensi dan Presentase Skor Nilai Peserta didik Siklus II

\begin{tabular}{|c|c|c|c|c|}
\hline No & Nilai Angka & Kategori & Frekuensi & Persentase $(\%)$ \\
\hline 1 & $0-60$ & Kurang Sekali & - & \\
\hline 2 & $61-65$ & Kurang & - & \\
\hline 3 & $66-75$ & Cukup & - & \\
\hline 4 & $76-85$ & Baik & 7 & $23,75 \%$ \\
\hline 5 & $86-95$ & Baik Sekali & 21 & $71,25 \%$ \\
\hline \multicolumn{3}{|c|}{ Jumlah } & 28 & $95 \%$ \\
\hline
\end{tabular}

Sumber Data : Peserta Didik IX 3 SMP Negeri 8 Palopo, tanggal 02 Agustus 2017.

Untuk lebih jelasnya gambaran tes hasil belajar peserta didik kelas IX 3 SMP Negeri 8 Palopo dapat dilihat pada diagram berikut :

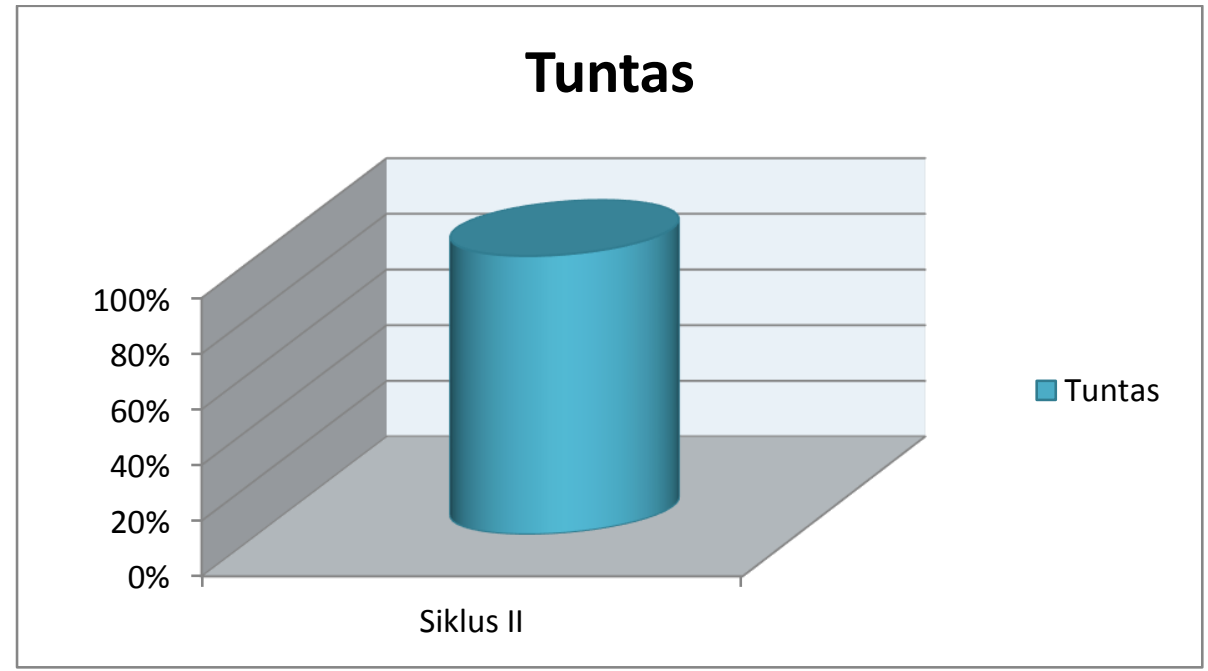

Gambar 2. Diagram ketuntasan belajar siklus II

Pembahasan

Sesuai dengan teori di atas penelitian tindakan kelas dengan menerapkan model kooperatif tipe Talking Stick pada mata pelajaran Pendidikan Agama Islam yang dilakukan dalam dua siklus didapatkan data bahwa peserta didik kelas IX 3 SMP Negeri 8 Palopo dapat menuntaskan KKM Al-Qur'an Hadist dengan baik dengan perolehan nilai rata-rata mencapai 88.53\%. Hal ini dapat dilihat dari peningkatan hasil belajar peserta didik mulai dari nilai awal peserta didik, siklus I dan siklus II.

Adapun data perincian tentang skor hasil belajar peserta didik selama penelitian dari tahap sebelum tindakan, siklus I sampai siklus II yaitu sebagai berikut : 
Tabel 4. Gambaran Tingkat Hasil Belajar Peserta didik

\begin{tabular}{|l|l|l|l|}
\hline \multirow{2}{*}{ Hasil Tes } & \multicolumn{3}{|c|}{ Skor Perolehan Hasil Tes Belajar Peserta didik } \\
\cline { 2 - 4 } & \multicolumn{1}{|c|}{ Maksimal } & Minimal & Rata-rata \\
\hline Data awal & 88 & 60 & $68,46 \%$ \\
\hline Siklus I & 91 & 72 & $79,25 \%$ \\
\hline Siklus II & 95 & 80 & $83,53 \%$ \\
\hline
\end{tabular}

Sumber Data : Peserta Didik IX 3 SMP Negeri 8 Palopo, tanggal 12 Agustus 2017.

Dari tabel di atas dapat dipahami adanya peningkatan hasil belajar peserta didik dari setiap siklus, yaitu data awal peserta didik memperoleh nilai rata-rata 68,46 , pada siklus I nilai rata-rata peserta didik 79,25 , dan pada siklus II nilai rata-rata peserta didik mencapai 83,53. Dengan demikian dapat disimpulkan bahwa model kooperatif tipe Talking Stick mampu meningkatkan hasil belajar peserta didik pada mata pelajaran Pendidikan Agama Islam materi Al-Qur'an Hadist peserta didik kelas IX 3 SMP Negeri 8 Palopo semester 1 tahun ajaran 2017/2018

Untuk lebih jelasnya gambaran tingkat hasil belajar peserta didik selama penelitian pada mata pelajaran Pendidikan Agama Islam kelas IX 3 SMP Negeri 8 Palopo dapat dilihat pada diagram berikut :

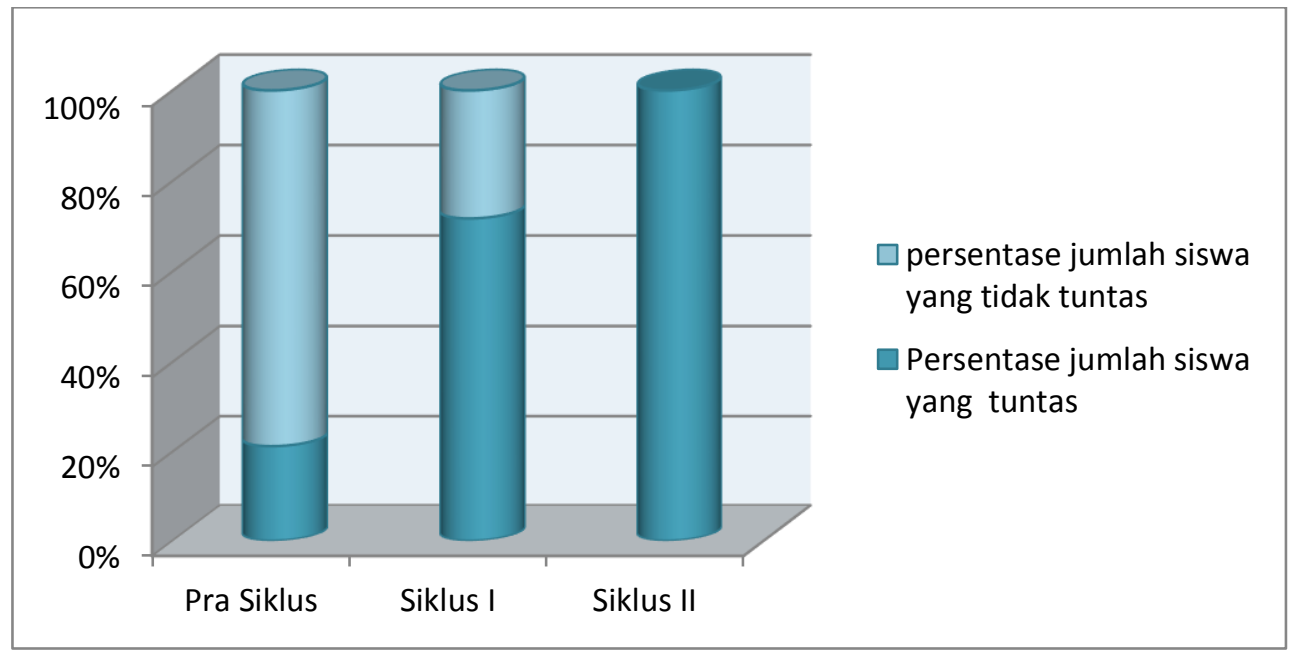

Gambar 3. Diagram ketuntasan belajar

Pengembangan keterampilan memahami Al-Qur'an Surah At-Tin melalui model kooperatif tipe Talking Stick merupakan suatu usaha untuk meningkatkan pengetahuan tentang Al-Qur'an Surah At-Tin pada peserta didik yang merupakan awal dari pembelajaran Al-Qur'an Hadist dengan baik dan benar. Seperti membaca QS At-Tin dengan Tartil, menyebutkan arti QS At-Tin, menjelaskan makna QS At-Tin.

Jadi dalam mengenal Al-Qur'an Surah At-Tin Peserta didik harus memahami maknanya. Dalam proses pembelajaran tersebut guru harus mempunyai model yang bervariasi dalam pelajaran Pendidikan Agama Islam 
(PAI), khususnya pembahasan tentang Al-Qur'an Surah At-Tin. Seperti model Talking Stick yang mengajarkan peserta didik dengan menggunakan tingkat (Stick), menggunakan bahasa Indonesia dalam mengajarkan Al-Qur'an Surah At-Tin, dan sebaginya. Karena model yang baik adalah model yang mendorong anak untuk belajar dengan baik.

Jadi dapat diambil kesimpulan bahwa tujuan pengembangan keterampilan adalah untuk meningkatkan mutu dan kualitas pembelajaran membaca akida secara harfiah. Sedangkan memahami ajaran Al-Qur'an Surah At-Tin adalah Termasuk Surah Mahkiyah (Diturunkan Sebelum Nabi Muhammad Saw. Hijrah Ke Madinah) Surat At-Tin Terdiri Dari 8 Ayat .

\section{Penutup}

Model Talking Stick dapat meningkatkan hasil belajar di sekolah diketahui bahwa nilai rata-rata peserta didik kelas VII9 sebelum diterapkan Model Talking Stick 68,46\%Pada siklus I peneliti telah menerapkan Model Talking Stick dengan model belajar secara kelompok dan skor hasil kompetensi peserta didik mencapai 79,25\%. Tetapi skor hasil penelitian belum maksimal sehingga peneliti merencanakan perbaikan yang akan diterapkan pada siklus II maka hasil proses pembelajaran dengan model Talking Stick meningkat menjadi 83,53\%.

\section{Daftar Pustaka}

Al-Abrasyi, Moh. Athiyah, Dasar-Dasar Pokok Pendidikan Islam, Jakarta, Bulan Bintang.

Ahmadi, Abu Dan Nur Uhbiyti, Ilmu Pendidikan , Jakarta, Rineka Cipta, 1991. Anurahman, Belajar dan Pembelajaran, Cet. VIII; Bandung: Alfabeta, 2013

Arief, Armai, Pengantar Ilmu dan Metodologi Pendidikan Islam, Jakarta, Ciputat Pres, 2002.

Arikunto Suharsimi, dkk., Penelitian Tindakan Kelas, Cet. VII; Jakarta: Bumi Aksara Press 2009

Arikunto Suharsimi, Prosedur penelitian, Suatu Pendekatan Praktik, Yokyakarta; Cet. XIII, Rieka Cipta, 2016

Ahmad, Sabri, Strategi Belajar Mengajar Dan Micro Teaching, Jakarta, Quantum Teaching, 2005.

Effendi Sofian dan Masri Singarimbun, Metodelogi Penelitian Survai, Jakarta:LP3ES, 1989.

http:/ainamulyana.blogspot.co.id/2015/02/model pembelajaran kooperatif tipe.html.

Kementrian Agama RI, al-Qur'an dan Terjemahnya, Solo, 01 januari 2015.

Kunandar, Penelitian Tindakan Kelas Sebagai Pengembangan Profesi Guru, Cet. V, Jakarta, Raja Grafindo Persada, 2010. 
Martinus dan Bansu, Strategi Pembelajaran Kooperatif Learning , Bandung, Rajawali Press, 2009.

Mulyasa, E. Kurikulum Berbasis Kompetensi: Konsep, Karakteristik, Implementasi, Dan Inovasi, Bandung, Remaja Rosdakaria, 2008.

Muhaimin, Paradikma Pendidikan Islam: Upaya Mengefektifkan Pendidikan Agama Islam di Sekolah, Bandung, Remaja Rosdakarya, 2004.

Muktar, Desain Pembelajaran Pendidikan Agama Islam, Jakarta, Misaka Galisa, 2013.

Nasution, S. Metode Research: Penelitian Ilmia, Cet, Xi, Jakarta, Bumi Aksara, 2009.

Ramayulis Dkk, Filsafat Pendidikan Islam, Jakarta: Kalam Mulia, 2011.

S. Syamsu , Strategi Pembelajaran Meningkatkan Kompotensi Guru, Aksara Timur, September 2015.

Syah, Muhibbin, Pisikologi Pendidikan Dengan Pendekatan Baru, Bandung, Remaja Rosdakarya, 2006.

Shoimin, Aris, 68 Model Pembelajaran Inovatif dalam Kurikulum 2013, Yogyakarta, Juni 2016.

Sugiono, Anas, Pengantar Evaluasi Pendidikan, Jakarta, Raja Grafindo Persada, 2008.

Sudjana, Nana, Penilain Hasil Proses Belajar Mengajar, Bandung, Remaja Rosdakarya, 1999.

Usman Moh.Uzer, Menjadi Guru Profesional, Cet. X, Bandung: Remaja Rosdakarya, 1999 